\title{
Sphingosine-1-phosphate is a novel biomarker in sepsis severity
}

\author{
A Nierhaus ${ }^{1}$, MS Winkler ${ }^{2 *}$, M Holzmann² ${ }^{2}$ E Mudersbach ${ }^{3}$, A Bauer $^{2}$, L Robbe $^{2}$, C Zahrte $^{1}$, E Schwedhelm $^{3}$, \\ G Daum ${ }^{4}$, S Kluge ${ }^{1}$, C Zoellner ${ }^{2}$ \\ From ESICM LIVES 2015 \\ Berlin, Germany. 3-7 October 2015
}

\section{Objectives}

Sepsis is characterized by capillary leakage followed by organ dysfunction. Sphingosine-1-phosphate (S1P) is a signalling lipid that regulates endothelial permeability. Here we investigated whether serum S1P concentrations are associated with sepsis severity.

\section{Methods}

Primary outcome variable was the serum S1P concentration quantified by mass spectrometry. Blood was drawn at day of enrollment. S1P was correlated with inflammatory markers and Sequential Organ Failure Assessment Score (SOFA) score for sepsis severity.

\section{Results}

All three groups of patients had significantly $(\mathrm{P}<0.001)$ lower serum S1P concentrations than controls (median $457.9 \mu \mathrm{g} / \mathrm{L}$; interquartile range, IQR 379.8-562.3 $\mu \mathrm{g} / \mathrm{L}$ ). The lowest S1P concentrations was found in the septic shock group (149.1 $\mu \mathrm{g} / \mathrm{L}$; IQR, 105.1-163.2 $\mu \mathrm{g} / \mathrm{L})$ compared to patients with severe sepsis $(234.7 \mu \mathrm{g} / \mathrm{L}$; IQR, 185.4-342.6 $\mu \mathrm{g} / \mathrm{L})$ and sepsis $(246.7 \mu \mathrm{g} / \mathrm{L}$; IQR, 201.7$306.0 \mu \mathrm{g} / \mathrm{L}$ ). S1P levels were positively correlated with high-density lipoprotein (HDL), and red blood cell count (RBC) and negatively correlated with: procalcitonin, interleukin-6, C-reactive protein and lactate. In a multivariate linear regression model S1P, HDL and RBC were significantly associated with SOFA score $(\mathrm{P}<0.001)$. S1P concentration below $158.2 \mu \mathrm{g} / \mathrm{l}$ was the most potent indicator for diagnosing sepsis with shock compared to all other inflammatory markers. In a multivariate logistic regression model calculated for prediction of septic shock the Odds

\footnotetext{
${ }^{2}$ University Medical Center Hamburg-Eppendorf, Department of Anaesthesiology, Hamburg, Germany

Full list of author information is available at the end of the article
}

ratio for S1P was 0.97 (CI 95\% 0.96-0.99) and the best predictor of shock $(\mathrm{P}<0.01)$ among all parameters tested.

\section{Conclusions}

$\mathrm{S} 1 \mathrm{P}$ is an indicator of sepsis severity and superior to predict septic shock than currently established markers. Further prospective studies are needed to confirm the results in a larger cohort of non-septic patients and controls.

\section{Authors' details}

'University Medical Center Hamburg-Eppendorf, Department of Intensive Care Medicine, Hamburg, Germany. ${ }^{2}$ University Medical Center HamburgEppendorf, Department of Anaesthesiology, Hamburg, Germany. ${ }^{3}$ University Medical Center Hamburg-Eppendorf, Institute of Clinical Pharmacology and Toxicology, Hamburg, Germany. ${ }^{4}$ University Heart Center, University Medical Center Hamburg-Eppendorf, Clinic and Polyclinic for Vascular Medicine, Hamburg, Germany.

Published: 1 October 2015

doi:10.1186/2197-425X-3-S1-A789

Cite this article as: Nierhaus et al:: Sphingosine-1-phosphate is a novel biomarker in sepsis severity. Intensive Care Medicine Experimental 20153 (Suppl 1):A789.

Submit your manuscript to a SpringerOpen ${ }^{\bullet}$ journal and benefit from:

- Convenient online submission

- Rigorous peer review

- Immediate publication on acceptance

- Open access: articles freely available online

- High visibility within the field

- Retaining the copyright to your article

Submit your next manuscript at $\boldsymbol{\nabla}$ springeropen.com

\section{SpringerOpen ${ }^{\odot}$}

(0) 2015 Nierhaus et al.; This is an Open Access article distributed under the terms of the Creative Commons Attribution License (http:// creativecommons.org/licenses/by/4.0), which permits unrestricted use, distribution, and reproduction in any medium, provided the original work is properly cited. 